Editorial referring to the paper: Torz C, Poletajew S, Radziszewski P. A prospective, randomized trial comparing the use of KTP (greenlight) laser versus eletroresection-supplemented laser in the treatment of benign prostatic hyperplasia. Cent European J Urol. 2016; 69: 391-395.

\title{
Lasers and the prostate
}

\author{
Stefan Buntrock
}

Citation: Buntrock S. Lasers and the prostate. Cent European J Urol. 2016; 69: 396.

Ever since its introduction in 1960, Light Amplification by Stimulated Emission of Radiation, in short: LASER has amplified and stimulated the hopes and imagination of patients and doctors alike. Laser even has a symbolic power that expands far beyond the walls of operation theatres. It holds a promise for the future, for technological progress and - a higher quality of treatment. Patients are not only satisfied, they are proud of being treated by laser. It means status to them and they will tell their friends about it. For doctors: let's face it, doing that Jedi knightthing in the OR is kind of cool.

Apart from that nimbus, where do we stand today, medically speaking? During the past ten years, the development of new lasers has had a substantial impact upon the landscape of surgical treatment of benign prostatic obstruction. We have seen the evolution of $60,80,120$ and 180 W KTP lasers, Holmium laser enucleation, Thulium laser vaporesection, Thulium laser enucleation and Diode laser evaporation and enucleation to name a few. Does technological advance translate into better treatment results? It depends. From a strict functional point of view, there does not appear to be much dif- ference compared to conventional loop resection. But with personalized medicine ante portas, possibilities have grown numerous to really tailor the right treatment for the right patient at the right time, depending on his prostate volume, coagulation status, etc. Investigation of this technology will go on. For instance, there are still question marks concerning possible thermal damage in the depth of the surrounding untreated tissue. In their prospective, randomized trial in this issue of CEJU, Torz, Poletajew and Radziszewski did not find any additional risk with the 80-W KTP laser when it comes to thermal damage of the external sphincter [1].

As for today, it appears that lasers are unlikely to vanish from the therapy landscape of benign prostatic obstruction. They are here to stay; so which laser and which method will it be in the future? In the 2016 guidelines of the EAU, only Holmium laser enucleation and $532 \mathrm{~nm}$ vaporization with the KTP laser received the highest level of evidence when it came to results comparable with conventional TUR-P for men with moderate to severe LUTS [2]. However, several methods are recommended with grade A. So for the moment, it is more or less up to you to choose your weapon.

\section{References}

1. Torz C, Poletajew S, Radziszewski P. A prospective, randomized trial comparing the use of KTP (greenlight) laser versus eletroresection-supplemented laser in the treatment of benign prostatic hyperplasia. Cent European J Urol. 2016; 69: 391-395.
2. Gravas S, Bach T, Drake M, et al. EAU Guidelines 2016: Treatment of Non-neurogenic Male LUTS. Available online at: https://uroweb.org/ guideline/treatment-of-non-neurogenicmale-luts/
Corresponding author Stefan Buntrock, M.D. info@buntrock-urologie.de 